\title{
THE SOCIAL AND ETHICAL SIGNIFICANCE OF MUSIC AND MUSIC EDUCATION ${ }^{1}$
}

\author{
WAYNE BOWMAN \\ Brandon University (Canada) \\ bowmanwd@icloud.com
}

\begin{abstract}
Infatuated with efficiency and technical rationality, music educators have gravitated toward training rather than education, toward definitive answers rather than better questions. Our understandings of music, of education, and of music education are in urgent need of repair. A crucial part of that project is recovery of their nature as ethical and ethically-guided practices as rich resources for exploring crucial questions about what kind of people music making and musical education should enable us to become.
\end{abstract}

Keywords: Music education. Ethical practices. Social significance.

\footnotetext{
${ }^{1}$ A version of this essay was delivered as a part of an address to the Central Conservatory of Music, Beijing, China in September, 2015.
} 


\section{INTRODUCTION}

As my abstract suggests, the central theme of this essay is a rather provocative one. Originally I had in mind an equally provocative title: "What's Educational About Music Education?" Although that question is actually a fairly good fit to what I will pursue here, it looks suspiciously rhetorical at first gloss. And as you know, rhetorical questions are bad philosophical form, notorious for generating more heat than light. Let's assume this question is a serious one-one that seeks an actual answer-and see where it might take us.

It's not hard to imagine a defensive response going something like this: "Because music is unquestionably valuable, teaching it is profoundly and selfevidently educational. To suggest otherwise is irresponsible." Or, put another way, "Since music is intrinsically good, the institutions and processes devoted to teaching it have obvious and indisputable educational value. End of story."

I very much disagree with these claims, and hope you will set aside your deeply held convictions long enough for me to explain why. To be clear, though, it is not my intent to dismiss the educational potentials of music education. On the contrary, teaching music may indeed be educational, and profoundly so. It's just that this is not always or necessarily (or even usually?) the case. Teaching music, even teaching it efficiently and thoroughly, may or may not be educational. The institutions and the methods we employ to teach music may actually undermine educational outcomes. This places enormous responsibility on those of us who devote our lives to teaching music, responsibility it would be a serious mistake to neglect.

Teaching (even teaching something as wonderful and wondrous as music) can open minds, but it can also close them. Music teaching can nurture creativity, but it can also (and regrettably, it often does) suppress the imagination. It can help develop self-reliance and independence, but it can also make students docile and compliant. It is essential therefore that we think carefully about the differences between teaching music and music education.

Unfortunately, music teacher training programs mostly ignore issues like these. Our overwhelming concern seems to be to teach music (or to teach prospective teachers how to teach a given musical practice) methodically and efficiently. We teach people how to teach, in other words, but not about the ways teaching may fall short of ends that are genuinely educational. We have become exceptionally good at training teachers and teaching them to develop their students' musical skills, but we seldom ask if the outcomes of such instructional efforts are truly educational, or in what sense.

The philosopher John Dewey claimed that the arts are important because they help alleviate the "prejudice" that objects have fixed, inalterable value. But why do we need to eliminate the idea of fixed, inalterable value? What's 
wrong with it? In what ways is it "prejudicial"? The short answer is that values are human constructs-not fixed or inalterable entities-and in order to thrive in the ever-changing human world our ideas must be pliable, flexible, ever responsive to changing circumstances. The pragmatic view advanced by Dewey is grounded in convictions that action, not consciousness or representation of some "thing" called "reality" is the foundation of human life. Action-what we do-is foundational: not thinking, not abstraction, and not the "objects" to which these give rise. Human life is more like riding on a rapidly moving train than sitting perched on a mountain top somewhere. From pragmatist perspective, the world is always moving and changing. And in a changing world, as Dewey rightly warned us, rigidity can be a dangerous thing.

I'm afraid our approaches to music teaching present quite a significant contrast to this way of thinking. They are designed to prepare us for what is or what has been rather than for what may be or what is about to be. Our methods and institutions are designed to orient and prepare learners for the status quo rather than how to thrive amidst unpredictability or change. Music teaching often embraces past practice rather than musical futures. It seeks to transmit what "is," or what once was, rather than preparing students to contribute meaningfully to musical practices that are in the process of emerging or that may be yet to emerge.

My view is that education needs to identify and embrace those aspects of teaching and learning that help people adapt in the face of transitions, changes, or breakdowns. Musical training prepares people for what is: it caters to, develops, and refines existing habits. Musical education by contrast develops the habit of changing habits-and nurtures the capacity to recognize when change has become a necessity. In short, education equips people (whether prospective teachers or the students they teach) to be good adaptive learners: to perform comfortably, flexibly, and imaginatively in situations that are novel, unpredictable, and unstable-musical situations to which past habits may not be well suited. In a changing musical world, rigidity is educationally counterproductive. Music is not a single, stable, uniform entity, but rather a mode of human action that is radically plural, ever-changing, ever moving, ever evolving. I especially like the way Christopher Small once put this: "There is no such thing as music."

I hope that you see that an important part of what I am alluding to in this particular account of education is the development of what we might call "life skills." These are not habits that are "purely musical" as we have been taught to think about such things. I'd like you to consider the possibility that there is no such thing as action that is "purely musical." The notion of a boundary between music and life, between music and the world, is a terribly misleading one, one that seriously distorts and compromises our understandings of music and its significance. The border between musical and everyday action is highly porous. The habits we develop though our 
musical actions become important parts of who we are-our character, our identities, and also of our collective identity, since music is invariably and inextricably social. Again, Christopher Small put it beautifully: "How we music is who we are." The habits formed in making music together music become essential features of who we are (and what "we" is taken to designate).

If music educators are to make good on the claim to being educators we must take considerations like these to heart. When teaching music we are not just developing and refining musical skills, we are exploring and shaping who we wish to become as individuals and as a society. The difference between this orientation and the one that typifies most current practice in our field has sometimes been described as a difference between teaching "in" (or "about") music and teaching "through" music. These are very different processes-so different, in fact, that they need different names. We should call the latter "education" and the former "training." While both are essential to the processes of teaching and learning, I submit that training has come to eclipse education in our field almost entirely. And I think I understand why: training is easier to execute and its success much easier to measure and assess. But again, training focuses on habits that lock in past practice rather than nurturing responsiveness to change and the capacity to contribute to it meaningfully. Training does not prepare us to thrive in or contribute meaningfully to unknown futures. Or at least it does not do so typically.

How do we prepare students and prospective teachers of music for futures that are likely to diverge from the present in fundamental ways? The short answer is, "We educate them." But that is obviously circular, at least if you accept the definition of education I have proposed. So let us think a little more carefully about what training and educating entail. When we undertake to train, we stipulate concrete, observable goals, develop explicit sequences for attaining them, and standardized procedures and assessing our success. Reducing or eliminating ambiguity is crucial to the process. In training, problems and unanswered questions are obstacles, distractions, impediments. The success of training, in contrast to educating, is measured by the efficiency and consistency with which ends are reached. Accordingly, predictability and control are fundamental concerns. The ideal of training, we might say, is the smoothly running machine: Avoidance of failure is key, and attention must be devoted primarily to means (adherence to step by step rules) rather than ends. In other words, training starts with ends that are unquestioned or absolute and devotes its full attention to refining the means by which to achieve them. Training is technical in nature and in focus. And importantly, when we train people we make them technicians. But technicians do not seek to question or modify the ends to which their actions are devoted-nor is it in the interest of effective training for them to do so. Training and its attendant recipes alleviate the need to think about ethical questions and problems; and indeed, those who are well-trained often become quite impatient with and intolerant of such questions and problems. This does 
not bode at all well for practices (in particular musical and educational practices) whose guidance systems are fundamentally ethical or whose aims are fundamentally educational.

Now, clearly, training is quite useful under certain circumstances-most notably where ends are fixed and incontrovertible, and where we are reasonably sure that things like ambiguity and problems can be eliminated without compromising important outcomes. However, education-again: preparation for an unknowable future, developing the habit of changing habits-involves creative risk-taking, comfort amidst potential turbulence, and an ever-present possibility of failure. I think this may have been what Canadian R. Murray Schafer had in mind when he urged that music educators teach music "on the verge of peril." (Such riskiness or "peril" is, note, precisely what our prevailing instructional methods and curricula seek to eliminate). In education, as distinct from training, problems are assets rather than obstacles. They are precious resources. They are not impediments to learning or indications of failure but rather pathways to discovery, opportunities for renewal and growth. Indeed, problems are crucial parts of what keeps practices (like education, and like music) alive and growing. In contrast to the process of training, education's goals are multiple, often ambiguous, and always subject to interrogation.

Perhaps most importantly for my purposes here, the goals of education are life enhancing. The success of education, then, is not gauged by technical efficiency - "how-to"-but by ethical fluency_-whether-to," "when-to," "towhat-extent-to." We measure the success of education not so much by the specific tasks it prepares us to perform as by what kind of people (and what kind of society) it enables us to become. Education is guided by and explores by the ever-open ethical question, "What kind of person is it good to be?" And the attendant question for music education must be, "How do music and music-making put me (or us) in touch with this?"

Of course, one of the reassuring things about training is that it gives students lots to learn and gives teachers lots to teach. Training keeps us very, very busy. But is it the right kind of busy-ness? Does training deliver enough? Does it accomplish the right things, the things we will most need to thrive as human beings and as a society in tomorrow's world? Again, training is preoccupied with eliminating perceived obstacles and avoiding failure-these being impediments rather than assets. Training is obsessed with things like standards, standardization: with "what works"-not unlike the processes MacDonalds uses to turn out near-identical fast food "meals" world-wide. Is music education's fondness for instructional techniques the Macdonaldization of music education? Where in the teaching/learning process do prospective music teachers or their students learn to ask crucial ethical questions like "Why?" or "To what ends?" or "What kind of people are we becoming?" and "What does this musical practice have to do with it?" 
However important training may be (and make no mistake, it is both useful and important), it invariably falls short of education. Education is a considerably thicker soup. Its concerns are things like creativity, adaptation, responsibility, and rightness of action. Problems and questions are among its most precious assets. Education involves the kind of sense-making people may eventually drape their lives around. The habits education seeks to nurture are not those devoted to preserving past or present practice, but with extending, modifying, or transforming them. Education accepts risk, nurtures responsibility and initiative, and seeks to create practitioners who can change the practice at hand-whether instructional, musical, or both-as needed, and who are astute at recognizing when such change is warranted.

Both training and education involve instruction and are both important. But they serve different ends. The act of teaching, of delivering instruction in itself, does not guarantee one or the other. Music educators are quite fond of control and predictability, though, and training has become our default instructional mode. We naively assume that educational outcomes will follow automatically from training done well, when in fact they seldom do. People who are trained develop habits that-however useful they may be for certain purposes-may actually threaten educational outcomes.

Latin actually had two different words for the contrasting processes I have been describing here: educare and educere. Educare meant "to mold or shape"-or, as I have been using the term here, to train. It was devoted to preparing the young to fit into existing patterns of belief and practice. Educare sought to dispense answers and to prepare its recipients to execute prescribed tasks skillfully.

Educere, on the other hand, meant "to draw out": a process involving transformation. It was the process of preparing the young for a changing world, of preparing them to identify and respond appropriately to problems not previously encountered and thus not anticipated. Where educare gravitates toward the provision of answers, educere places a premium on problems and questions. Educare sees learners as consumers of knowledge, while educere sees them as creators of new knowledge. Educere nurtures independence of mind, the courage to swim upstream against prevailing currents-and the ability to discern when that is necessary.

Now, clearly, educare is an important instructional concern for any society. Without it, learners would be condemned to fumble about, discovering everything for themselves, haphazardly. Responsible instruction must give learners the tools and skills required to function effectively and efficiently in the shared human world. At the same time, however, neglecting educere creates citizens incapable of recognizing and addressing new problems. It creates people who may know a lot and may be quite proficient at certain designated skills, but who are not comfortable charting new territory or adapting to change. Educare is technical; educere is ethical. 
My main points have been these: Teaching may train or it may educateprocesses that differ profoundly from each other. Both are important; both are necessary. But while training may contribute to education, it must not be misconstrued as a potential substitute. Training is incapable of creating an educated society. To educate, one must have been educated-must have developed the distinctive attitudes, dispositions, and character with which education is concerned. To be educated means that one is deeply involved in continual growth and renewal-concerns that are of little interest to training. Training has its place in music education, then; but it is not sufficient. And to believe it is educationally neutral or harmless is a serious mistake.

All this talk about training and education is fine, you may well be saying, but what's it got to do with music? I hope you will have seen that the connections are direct and profound. Where we accept the technical concerns of training as sufficient for instructional guidance, we neglect what I would argue are music's most important potential benefits. Learning in and about music are trivial compared to what we learn through musical studycompared to the kind of people and the kind of societies to which creative and imaginative musical engagement may lead. Of course all this depends upon how we teach music; upon what or whose music we teach; upon whom we consider the beneficiaries of our instructional efforts; upon how we gauge instructional success; and so on. Musical study can enrich or thwart the imagination. It can be a powerful force in addressing social, cultural, and environmental issues or it can be an entertaining but inconsequential (an "aesthetic") diversion. It can help us embrace and even thrive in an unforeseen future or it can be a comforting retreat from responsibility. The seductive lure of technical rationality-its promise to replace all questions with answers, to offer ready-made solutions to problems, to eliminate the need for ethical deliberation by providing us fool-proof formulas for action-is a danger toward which music teacher education needs to become more vigilant.

I hope you can see I am not suggesting that music's distinctive features are irrelevant to our understandings of music education. I am arguing instead that the value of music education depends upon how its potentials, powers, and affordances are made to serve important human social ends. If activities like music making and teaching are not good in themselves-and they are not - then we are professionally obliged to weigh rival courses of musical and instructional action in terms of their demonstrable, real-world benefits. All claims to the benefits of music study and musical experience depend on what or whose music we have in mind, on how it is taught or experienced, and on the evidence that the benefits claimed are indeed being attained.

Because the potential outcomes of music teaching and music making are multiple, diverse, and often at odds with one another, it matters a great deal how we think about them and how we engage in them. None of the benefits we like to claim for music study follow inevitably from acts of music teaching or music making. Whether our efforts enhance or suppress human thriving 
depends on a host of ethical considerations to which music educators currently devote very little attention. None of this negates music's educational potentials. It does mean, however, that there are no guarantees. And because there are no guarantees we are obliged as professionals to attend with the utmost care to the ends our efforts serve-to the ways they enable or subvert human thriving. We must choose our actions responsibly and be prepared to change them as needed.

How would it change our instructional habits and our curricula if music education were to embrace things like problems and ambiguity? If we were to teach on the verge of peril? If we were to conceive of music and teaching as fundamentally ethical endeavors-as precious resources for exploring questions like "What kind of person is it good to be?" and "In what kind of society do we want our children's children to live?" How might music uniquely lend itself to exploring issues like these? What might it really mean to be musically educated in the $21^{\text {st }}$ century?

Although these are questions whose adequate pursuit would take us well beyond this brief essay, here is how a response might begin. It would involve: (1) emphasis upon creativity and participatory (as distinct from presentational) performance, not just reinterpretations of pieces created by others; (2) getting over our obsession with definitive answers and replacing it with determination to ask better questions; (3) a shift away from ethnocentric exclusivity in favor of rich engagements in multiple musical practices that are truly diverse; (4) a focus on the potential benefits of music making for all rather than a select or 'talented' few; (5) commitment to developing artistic citizenship and civic responsibility, concerns that depart dramatically from the old notion of teaching "music alone."

In conclusion: Music Education, in contrast to mere training, is preparation for citizenship-what kind of person it is good to be, and what kind of societies we hope to forge through our (musical) actions. To important ends like these, certain musical and instructional practices are clearly better suited than others. The musically educated are prepared not just to replicate current practices but to transform, extend, and even resist them when needed. This places profound ethical questions-rather than preordained techniques and answers - at the heart of the process of music education.

With this as background, perhaps "What's Educational About Music Education?" is not such a bad question after all. Rather than implying that music education is educationally vacuous, it offers a crucial reminder that educational outcomes are potentials, not guaranteed outcomes of music teaching and music making. Teaching music-even teaching it well-though necessary, is not sufficient to music education. 
Dr. Bowman has taught at Brandon University in Manitoba, Canada, Mars Hill College (North Carolina), and has held visiting professorships at the University of Toronto and New York University. His scholarly work is widely known in the music education profession. His books include: Philosophical Perspectives on Music (1998, Oxford University Press) and The Oxford Handbook of Philosophy in Music Education (2012, in collaboration with Dr. Ana Lucia Frega). He helped found the scholarly journal Action, Criticism, and Theory for Music Education, and served as its Associate Editor for ten years. 